\title{
Thyroid Gland Langerhans Cell Histiocytosis
}

National Cancer Institute

\section{Source}

National Cancer Institute. Thyroid Gland Langerhans Cell Histiocytosis. NCI Thesaurus.

Code C156407.

Langerhans cell histiocytosis involving the thyroid gland focally or diffusely. It is exceedingly rare and usually occurs in patients with multifocal disease. 